\title{
THE DUAL FORM OF EDUCATION AS A COMPONENT OF INTEGRATION PROCESSES IN THE EDUCATIONAL ENVIRONMENT
}

\author{
Olha Kravchenko
}

The most important characteristic feature of the current stage of development of higher education in Ukraine is integration processes that reflect, on the one hand, substantive and structural changes within the education system, and on the other hand, the processes of interaction between education and the production sphere. The priorities of state policy and the concept of innovative development in the field of education indicate the necessity to form a wide range of mechanisms for cooperation between business and educational institutions. In the educational standard of higher education in specialty it is noted that the future specialist must be ready for the following activities: production and technological activities, project activities, research activities, organizational and management activities. Specific types of professional activity, for which a specialist is mainly prepared, are determined by higher educational institutions in cooperation with students, teachers, and employers' associations. With such an essential range of requirements for future specialists, there is a need for qualitative changes in the content and organization of training.

In modern social and economic conditions, the activities of higher education institutions that train specialists for the food industry are associated with solving a number of problems: the imperfection of the mechanisms of social partnership between educational institutions and employers; insufficient practical orientation in the training of qualified personnel for a particular enterprise; inconsistency of the educational and resource base of educational institutions. As a result of the search for effective forms of organizing of the educational process for solving the tasks set before education, the introduction of elements of dual education in the educational process seems to be expedient, promising, and of current interest

Keywords: specialist, learning process, dual education, production, professional competency, cluster

How to Cite:

Kravchenko, O. (2021). The dual form of education as a component of integration processes in the educational environment. ScienceRise: Pedagogical Education, 2 (41), 27-30. doi: http://doi.org/10.15587/2519-4984.2021.228241

(C) The Author(s) 2021

This is an open access article under the CC BY license (http://creativecommons.org/licenses/by/4.0).

\section{Introduction}

Large-scale transformations of the socioeconomic system of the state necessitate the modernization of the educational environment. In modern conditions, a number of tasks are being actualized for training highly qualified, competitive specialists, updating the human resources of Ukrainian society and strengthening the practical orientation of higher education. Such educational tasks are determined by the specific historical conditions of the life of society. Their solution requires the involvement of new models of educational activities, updating methods for monitoring the quality of education, encourages a change in the ratio of state and non-state impact on the development of higher education, establishing interaction between the state, educational institutions and enterprises as social partners. One of the conditions for updating and improving the educational process in the preparation of future specialists is the strengthening of interaction between universities and business entities (enterprises, organizations), the formation of professional competence of applicants for education in accordance with the requests of potential employers, in the conditions of modern production. In this aspect, the implementation of the dual form of education, which has received worldwide recognition, which is of particular importance.

\section{Literature review}

Integration processes in the higher education system are studied in various aspects. Scientists are considering the issues of modernizing the educational environment [1, 2], improving the professional competence of future specialists [3], the effectiveness and feasibility of introducing a dual form of education in the preparation of competitive production personnel $[4,5]$, interaction between the production and educational spheres [6, 7]; the elements and components of the dual educational system [8], mechanisms of functioning and models of dual education [9] are characterized.

Despite a sufficient number of scientific papers, the mechanisms for implementing this process remain controversial. It is obvious that the characteristics of integration processes, their methodology, the features of the functioning of dual education as an effective mechanism of interaction between the state, educational institutions, business entities and education seekers remain controversial and require further substantiation and study. 


\section{The aim and objectives of research}

The aim of the article is to substantiate the features of integration processes and mechanisms of interaction between the educational and industrial environment.

According to this aim, the following objectives have been identified:

1. Determine the features of integration processes in the educational environment.

2. Justify the effectiveness of the dual form of education for the implementation of integration processes.

3. Analyze the current trends in the implementation of the dual form of education.

4. Determine the levels of integration of higher educational institutions, business entities, education seekers, government and administrative institutions.

\section{Materials and methods}

To achieve the aim, a systemic complex of research methods were applied: theoretical - analysis, synthesis, generalization of the content of pedagogical and educational-methodical literature in order to characterize the features of integration processes in the educational environment; comparison and abstraction - to determine the mechanisms and models of dual interaction of educational and work environment; generalization and systematization - for formulation of research findings.

\section{Research results}

The training of specialists for the branches of national production and the service sector in certain historical periods is based on various organizational and methodological principles that can't remain unchanged. Therefore, the main tasks of education are consonant with the processes of development and modernization of society, because it is the educational environment that is the source of providing humanity with production personnel and highly qualified specialists [1].

The dynamics of changes in educational tasks depends on the rate of renewal and improvement of the economic structure of modern society, the rate of development of various sectors of the national economy [10]. It is the requirements of the working environment and the needs of the labor market that determine the main tasks facing universities. This also applies to the requirements for the quality of training and qualifications of specialists [11].

High-quality training of applicants for education for professional activity, providing the labor market with competitive specialists, meeting the requirements of potential employers and the educational needs of the students themselves are the main challenges to the demands of the present [12]. Among the ways to implement these tasks, it is possible to see the attraction of the best world practices and educational models, among which the introduction of a dual form of education is very relevant, determines the practical orientation of the educational process, which ensures the interaction of the educational and industrial environment [13].

The introduction of integration processes in education presupposes the comprehension of duality as a multidimensional category, provides for the wellcoordinated interaction of an educational institution and business for the preparation of highly qualified specialists in various forms of education [4]. At the same time, the modern higher school is not able to independently solve the problems of improving the quality of training of applicants for education, their motivation for professional activity, adaptation to the first job. It is the interaction of the educational and industrial environment that accelerates the development of theoretical foundations, mechanisms and technologies of dual education for solving the problem of professional self-determination of future specialists [12].

Modern scholars note that the introduction of a dual form of higher education provides for:

- active participation of applicants for education in the implementation of the educational process;

- targeted training of specialists for certain sectors of the national economy;

- possibility of the applied use of knowledge and the formation of the competencies of future specialists in real production conditions;

- strengthening the practical component of the educational process;

- improving the content of education, a variety of forms of presentation of educational material;

- approach to learning as a collective learning activity;

- improving the mechanisms of social partnership between educational institutions and business entities (enterprises, institutions, organizations, firms) [3].

The introduction of a dual form of education is a necessary component of the training of competitive specialists, overcoming the isolation of the theoretical and practical components of education on the basis of social partnership of enterprises and educational institutions is [7, 14].

The use of duality elements determines the overall coordination of the educational process by the state, the educational institution and the enterprise (the business partner of the educational institution) [11]. Consequently, responsibility for the learning outcome is shared between the enterprise and the educational institution.

The dual form of education is aimed at improving and updating the content of the educational process, expanding the number of educational programs, creation of a new educational and production environment and acts as an effective mechanism for solving many social problems (Fig. 1).

Among the listed areas, let's consider the strengthening of integration processes in the system "educational institutions - applicants for education - business entities - management structures" to be the most important. The mechanisms of such integration include the creation of educational-production and educationalscientific-production clusters. Such clusters are innovative structures that ensure the implementation of a dual form of education. There are also more complex constructs that provide integration processes in the educational environment. These include systemic educational and scientific complexes, the structure of which includes educational institutions, enterprises of various types, types, forms of ownership, innovative educational programs, technologies, management structures. The purpose of the activity of each such complex is the integration of educational and production resources of a certain territory, creating conditions for the identification and development of educational personality potential. 
Modernization and variety of content and forms of the educational process

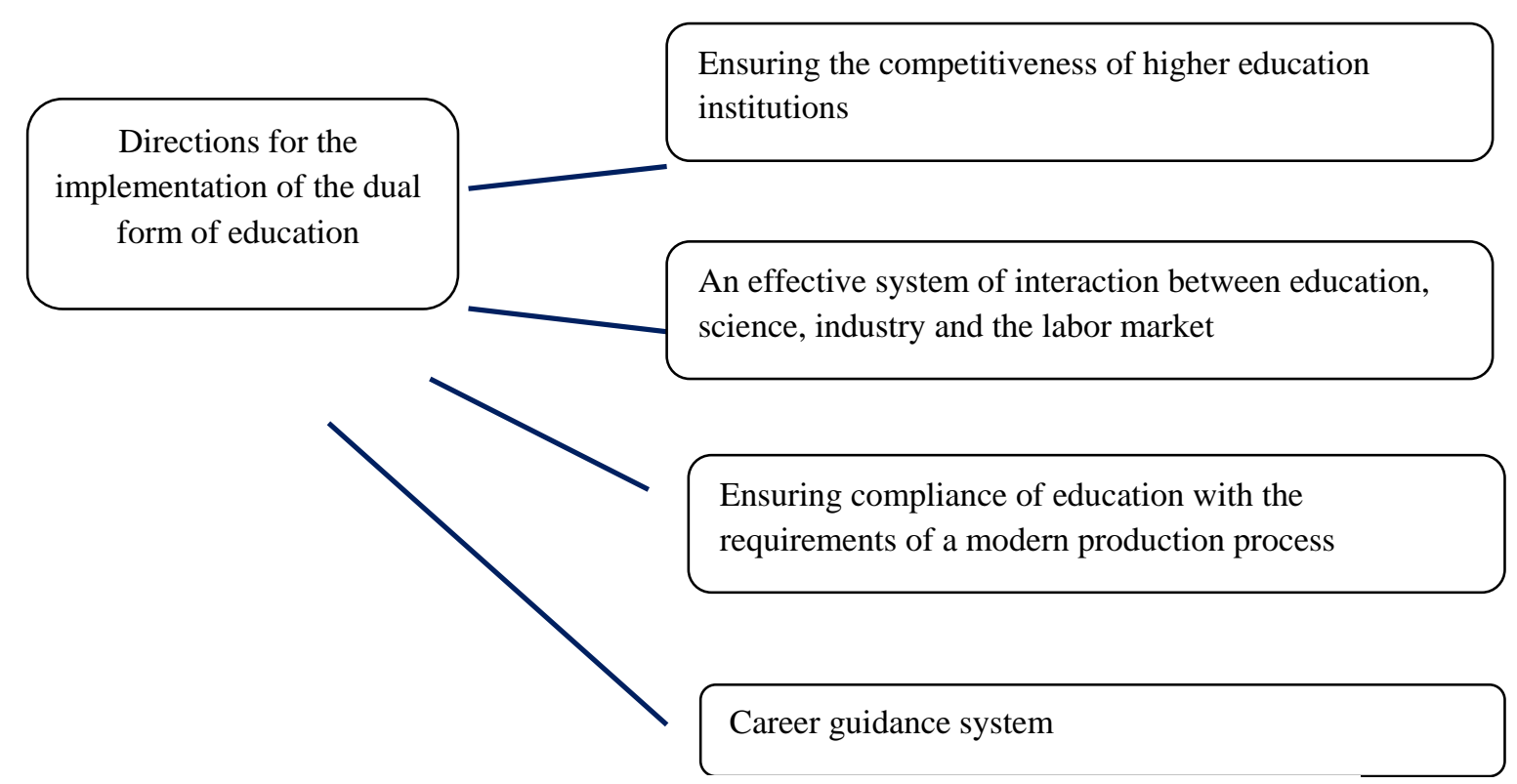

Fig. 1. Directions for the implementation of the dual form of higher education

In general, the concept of "scientific and educational complex" should be interpreted as integration within a certain territory of educational institutions, scientific institutions, governing bodies, dual enterprises that are in close cooperation and provide a high level of training for this industry. Educational-scientific complexes and educational-scientific-production clusters reflect the interconnection and interdependence of educational institutions, business entities, management structures to create a large-scale, multifunctional, high-tech educational and production macrosystem, which provides training of highly qualified specialists [15]. The criteria for the integration of the subjects of the dual educational process include:

- horizontal (provides for the implementation of educational programs of the same level). Educational integration is built at the local, regional, state levels.

- vertical (characterized by the implementation of various educational programs). Educational integration, lined up vertically, includes: institutions of vocational education, institutions of higher education, institutions for advanced training and retraining, continuous education of specialists;

- organizational (characterized by varying degrees of independence of dual partners: educational institutions, enterprises, institutions, etc.) [15].

\section{Discussion of research results}

With the aim of a holistic view of the integration processes in the educational environment, the features and advantages of the dual form of education were analyzed. It is noted that the introduction and functioning of the dual form of receiving enhances the interaction of educational institutions and business entities as social partners [7, 9]. Among the organizational aspects and mechanisms for the implementation of integration processes, the creation of educational and scientific complexes, clusters, are educational entities capable of providing the training of competitive, mobile, creative specialists adapted to industrial realities [2]. Such integration can be built along horizontal, vertical and organizational approaches.

\section{Conclusions}

1. It has been established that the features of modern integration processes of the educational environment are associated with the introduction of a dual form of education.

2. The implementation of integration processes is ensured through social partnership and interaction between educational institutions and business entities, the creation of educational and scientific complexes, educational and industrial and educational, scientific and industrial clusters. By "educational and scientific complexes" let's mean structural subjects that provide a dual educational process aimed at high-quality practical training and adaptation of applicants for education to the processes and requirements of the working environment. Let's consider "educational, research and production clusters" based on higher educational institutions to be innovative structures that allow combining the theoretical aspects of education in educational institutions with practical ones on the basis of enterprises.

3. Among the topical directions of integration processes, vertical, horizontal, and organizational ones have been identified.

4. Let's associate the prospects for further scientific research with the study and development of a model of professional competence of future specialists in the dual form of education. 


\section{References}

1. Sharma, S. (2019). Democratic Values, Freedom, Control and Life Satisfaction. Economic Affairs, 64 (1), 217-231. doi: http://doi.org/10.30954/0424-2513.1.2019.26

2. Imashev, G., Kuanbayeva, B., Rakhmetova, M., Uteshkaliyeva, A., Tumysheva, A., Mardanova, L. et. al. (2020). The implementation of the specialized-education model at the present stage. Ad Alta-Journal of Interdisciplinary Research, 10/01 (X), $10-13$.

3. Sidakova, L. V. (2016). Suschnost i osnovnye priznaki dualnoi modeli obucheniia. Obrazovanie i vospitanie, 2, 62-64.

4. Vemyan, V. G., Ter-Hovhannisyan, V. G. (2015). Dual form of vocational education as a condition for effective solution of problems of modernization of education. Psychology: reality and prospects, 5, 29-34.

5. Apergis, N. (2018). Education and democracy: New evidence from 161 countries. Economic Modelling, 71, 59-67. doi: http://doi.org/10.1016/j.econmod.2017.12.001

6. Khomenko, V. (2016). Vyznachennia ta obgruntuvannia zahalnonaukovykh osnov rozrobky systemy dualnoho zmistu profesiinoi pidhotovky maibutnikh inzheneriv-pedahohiv. Ukrainian Journal of Educational Studies and Information Technology, 4 (2), 56-63.

7. Kravchenko O., Starova T., Nykyforov R. World models of dual education and features or their functioning. AD ALTA: journal of interdisciplinary research. 2021. Vol. 11/01 (XV). P. 87-91.

8. Oleksin, Yu. P., Jakubowski, S. S. (2019). Pedagogical supervision as an element of individualization of dual training. Young Scientist, 4.1 (56.1), 102-105.

9. Kulalaieva, N., Leu, S. (2019). Dual education as a tool for assurance the education of sustainable development. International Journal of Pedagogy, Innovation and New Technologies, 6 (2), 104-115. doi: http://doi.org/10.5604/01.3001.0013.6847

10. Drew, C. Education for Sustainable Development, Explained! Aavailable at: https://helpfulprofessor.com/education-forsustainable-development/

11. Grigoreva, N. V., Shvets, N. A. (2016). The model of training specialists in dual-education environment. Modern problems of science and education, 6. Available at: https://science-education.ru/ru/article/view?id=25763 Last accessed: 17.03 .2021

12. Slozanska, H. I. (2016). Dotsilnist zastosuvannia modeliuvannia profesiinoi diialnosti u pidhotovtsi maibutnikh fakhivtsiv VNZ. Aktualni problemy humanitarnykh nauk u doslidzhenni molodykh vchenykh. Kyiv, 241-243.

13. Ovsienko, L. V., Zimina, I. V., Esenina, E. Iu. (2014). Dualnoe obuchenie kak vazhnii faktor povysheniia investitsionnoi privlekatelnosti regiona. Vestnik Kazanskogo tekhnologicheskogo universiteta, 17 (5), 339-344.

14. Andreitsiv, I. (2017). Shcho take dualna osvita i navishcho vona ukraintsiam. Ukrainska pravda. Available at: https://life.pravda.com.ua/society/2017/02/16/222630/ Last accessed: 21.03.2021 $15-21$

15. Iliv, O. V. (2014). Educational complex as an object of social and geographical research. Geograficheskii vestnik, 2 (29),

Received date 10.02.2021

Accepted date 16.03.2021

Published date 31.03.2021

Olha Kravchenko, PhD, Department of Chemistry and Methods of its Teaching, Kryvyi Rih State Pedagogical University, Gagarina ave., 54, Kryvyi Rih, Ukraine, 50086

E-mail: gluschenkoo@ukr.net 